\section{Pasteur takes US company to court \\ Paris}

ThE Pasteur Institute, which holds the patent rights for the test kit used to detect the second human immunodeficiency virus (HIV-2) known to cause AIDS, and Diagnostics Pasteur, which holds the exclusive licence to these rights, has accused the US company, DuPont de Nemours Inc., as well as its French, Swiss and Belgian subsidiaries, of patent infringement.

HIV-2 was first isolated by researchers at the Pasteur Institute in 1985 and a number of patents protecting the diagnostic test were taken out in France and abroad at the beginning of 1986. Diagnostics Pasteur was awarded the exclusive rights to develop a commercial test kit for HIV-2.

According to the Pasteur Institute, DuPont de Nemours developed a copy of the test kit without authorization.

This is the second time the Pasteur Institute has been involved in a legal wrangle over patent rights to an AIDS virus test kit. A protracted dispute between the Pasteur and the US Department of Health and Human Services (HHS) over who first isolated the HIV-1 virus - and therefore could claim rights to the antibody test kit was finally resolved in March last year when both parties acknowledged the 'joint invention' of the kit and agreed to share the patent rights (see Nature 326, 533; 1987).

Peter Coles

\section{New AIDS institute}

\section{Boston}

HARVARD University last week announced plans for a university-wide institute to "expand and accelerate AIDS research".

Virologist Myron Essex, currently head of the Department of Cancer Biology at the Harvard School of Public Health, will head the new institute. He will be joined by senior Harvard investigators including William Haseltine, Martin Hirsch and Jerome Groopman.

Essex stressed that an important overall objective of the AIDS institute is to involve more than just experts in virology and immunology. In addition to biological and clinical studies, research centres will be established in epidemiology, policy and education, and international cooperation. Essex emphasized that the enterprise will be more than a new label on existing efforts, saying that he anticipates "think tank sessions", regular meetings among senior investigators and a "high level of interdisciplinary cooperation". At least 70 Harvard faculty members are expected to participate in the institute.

One impetus for the new institute is the desire to help attract more funding from the government, foundations and industry for AIDS research.

\title{
Commercial venture to speed up AIDS drug tests in California
}

\section{Berkeley}

A NOVEL attempt to accelerate the testing of new AIDS drugs has been launched by the new San Francisco company ViRx Medical Group, founded with backing of $\$ 1.5$ million from the Boston venture capital firm of Burr, Egan, Deleage and Company.

ViRx opened its San Francisco clinic last week for patients infected with human immunodeficiency virus (HIV), and now plans to solicit drug-testing contracts from pharmaceutical companies. ViRx boasts of a roster of consultants with expertise in drug development and AIDS virology, including French AIDS researcher Luc Montagnier of the Pasteur Institute.

The company's founders say they are motivated less by profit than by a desire to find effective drugs and make them rapidly available. Bruce Decker, company co-founder and principal consultant, who is himself an HIV patient, says that ViRx hopes to "shave years off the approval process". By building up a pool of several thousand patients whose conditions will have been monitored and recorded, it hopes to streamline the recruitment of subjects for studies. By speeding up efficacy testing, Decker hopes to see more promising drugs gain approval for wide distribution, as AZT did, even before the evaluation process is complete.

The clinic will provide patients with complete blood testing, counselling and monitoring at 30,60 or 90 day intervals, as well as advice on the available experimental drugs. Patients participating in studies will be monitored free of charge. ViRx hopes to attract patients by allowing them to choose the drugs they wish to take, rather than conducting placebocontrolled trials which, Decker says, may "no longer be defensible". Instead, ViRx aims to provide matched control groups of patients who have chosen to forego treatment or to take accepted treatments such as AZT

Decker is not worried that this open attitude toward drug trials could spread the patients into hopeless numbers of categories, at different stages of their disease and with a spectrum of drug histories. He says that promising drugs will bring patients flocking to participate in studies, when it should be possible to persuade them, for the sake of uniformity, to refrain from taking other less promising drugs. Thus Decker says he will have no problem attracting 400 people immediately for a study of dextran sulphate, an antiviral agent currently in vogue.

Companies using ViRx's service may take their test results for approval through the Food and Drug Administration (FDA) or through California's independent approval programme, which has been considering applications since January (see Nature 329, 476; 1987). An FDA spokesman says the agency prefers to see placebo-controlled trials, but may approve other controlled trials if they are properly designed.

Marcia Barinaga

\section{Another reminder of Chernobyl}

\section{London}

Two years and a day after the reactor explosion at Chernobyl - on 27 April - a leading Soviet atomic scientist died. Official obituaries have not given a cause of death for 51-year-old Academician Valerii Legasov, fuelling speculation that he was another victim of Chernobyl.

Legasov, who was deputy director of the Kurchatov Institute of Atomic Energy, was one of the team involved in investigating the cause of the Chernobyl incident, and in the clean-up that followed. The official death-toll remains at 31 , a figure regarded with scepticism by many of the local Kiev residents, according to a recent underground publication. Legasov's death comes at a time when the official media are campaigning to restore public confidence in nuclear power.

In spite of the setback at Chernobyl, the Soviet energy programme remains irrevocably committed to nuclear power. Chernobyl-type RBMK graphite reactors are to be phased out in favour of the water-cooled VVER model, and plans for new power stations at Minsk, Krasnador and Chyhryn have been dropped. Otherwise, though, the programme continues as before. Suggestions that nuclear power stations should in future be sited in remote areas - or, as Academician Sakharov has suggested, deep underground - have been ignored. For the Soviet nuclear programme will eventually be expected to produce not only electrical energy but also hot water for district heating, and the plants will need to be located close to cities.

The campaign to re-establish the good name of the nuclear power industry has made much of the improved training and psychological assessment of power station workers, and the new Spetsatom service for phasing out and mothballing obsolete plants. But Pravda quotes the local party committee as saying that the managers of the plant are still neglecting vital maintenance work. 